\title{
MECHANIKA ARYSTOTELESOWSKA \\ A WSPÓŁCZESNA FIZYKA \\ NA TROPACH CIĄGŁOŚCI WEWNĘTRZNEJ LOGIKI ROZWOJU NAUKI
}

\begin{abstract}
ARISTOTELIAN MECHANICS AND CONTEMPORARY PHYSICS:

TRACKING THE CONTINUITY OF THE INTERNAL LOGIC OF THE DEVELOPMENT OF SCIENCE

An analysis of two different reconstructions of Aristotelian mechanics in the language of contemporary physics reveals interesting aspects of the historical development of physics: (1) there exists a structural invariant in all physical representations of reality in the form of the Cartesian product and (2) all intertheoretical transitions to date, at each stage of unification, have occurred in accordance with the correspondence principle. This means that the historical development of physics can be regarded as rational in the sense that subsequent theories become ever more general and Aristotelian mechanics can be treated as a natural forerunner of Newtonian mechanics and, by extension, Einstein's relativity theory.
\end{abstract}

Keywords: fibre bundle, spacetime, Cartesian product, structural realism, correspondence principle, mechanics, symmetry

Sformułowana przez Arystotelesa dwa tysiące lat przed powstaniem nowoczesnej metody naukowej mechanika należy do dziedzictwa myśli, które wyłoniło się z przeświadczenia o racjonalnym charakterze przyrody. Przekonanie to związane było z demitologizacją dokonaną na przełomie VII i VI w. p.n.e. przez myślicieli jońskiej szkoły filozofii (por. np. Pedersen 2007: 4-7). Mimo dość powszechnego przekonania, że została sfalsyfikowana przez współczesną fizykę, mechanika arystotelesowska nadal wzbudza zainteresowanie fizyków i filozofów nauki. Widać to w podejmowanych próbach jej rekonstruk-

\footnotetext{
* Wydział Filozoficzny, Uniwersytet Papieski Jana Pawła II w Krakowie, ul. Kanonicza 9, 31-oo2 Kraków, e-mail: wojciech.grygiel@upjp2.edu.pl, ORCID: https://orcid.org/ooooo003-2599-0410.
} 
cji przy użyciu narzędzi sformalizowanej matematyki oraz rozważaniach, na ile można ją włączyć w logikę rozwoju fizyki wytyczoną przez takie osiągnięcia, jak mechanika newtonowska czy też szczególna i ogólna teoria względności (Penrose 1968, Trautman 1970, 1973, Raine, Heller 1981, Wróblewski 2007: 63-64). Poznawczą wartość wiedzy przednaukowej, w obrębie której mechanika arystotelesowska powstała, podkreślał na przykład Russell (2011: 13), traktując ją jako początek fizyki, stanowisko to podzielał też Einstein (2001: 251-257).

Głównym celem mojego opracowania jest wykorzystanie dwóch współczesnych rekonstrukcji mechaniki arystotelesowskiej do zanalizowania natury jej związków z mechaniką newtonowską. Na tej podstawie wskażę kryteria, które pozwalają włączyć mechanikę arystotelesowską w wewnętrzną logikę rozwoju teorii właściwą międzyteoretycznym przejściom od mechaniki newtonowskiej do szczególnej i ogólnej teorii względności Einsteina. Mechanika arystotelesowska nie musi być bowiem traktowana wyłącznie jako mglista teoria filozoficzna wyprowadzona z apriorycznych spekulacji i nieostrych pojęć. Można w niej widzieć strukturę poprawnie oddającą bardzo szczególną, lecz rzeczywistą sytuację fizyczną. Taka perspektywa pozwoli pokazać, w jaki sposób mechanikę arystotelesowską można dostosować do wymogów współczesnej metody naukowej.

Analizy rozpocznę od omówienia metodologicznych i pojęciowych aspektów adekwatności stylizacji potrzebnych, by oddać mechanikę arystotelesowską w języku współczesnej fizyki. Następnie zrekonstruuję czasoprzestrzeń mechaniki arystotelesowskiej za pomocą pojęcia wiązki włóknistej - abstrakcyjnego narzędzia współczesnej matematyki. Pozwoli to precyzyjnie ująć treść fizyczną tej teorii oraz wydobyć swoistość strukturalnych przemian przy przejściu do mechaniki newtonowskiej. Rozważania te uzupełnię wynikami otrzymanymi w modelu mechaniki arystotelesowskiej zaproponowanym przez Carla Rovellego (2015). Model ten okazuje się szczególnie użyteczny do wyeksplikowania funkcjonowania zasady korespondencji między mechaniką arystotelesowską i mechaniką newtonowską.

Przeprowadzone analizy pozwolą odpowiedzieć na pytanie, pod jakimi warunkami można uznać mechanikę arystotelesowską za prekursorkę współczesnych teorii fizycznych. Ostatecznie dzięki przedstawionym rozważaniom można lepiej ująć ciągłość rozwoju nauki od czasów starożytnej Grecji i pokazać, że w ściśle określonym obszarze swojej empirycznej adekwatności myślenie przednaukowe dostarczało rzetelnej wiedzy przyrodniczej. 


\section{DLACZEGO WARTO STYLIZOWAĆ HISTORIĘ?}

Rekonstrukcje mechaniki arystotelesowskiej przy użyciu współczesnych narzędzi teoretycznych napotykają pojęciowe i metodologiczne trudności, ponieważ są nieodłącznie związane ze znaczną stylizacją historyczną (por. Heller 1993: 9-12, 35-36). Współczesne teorie fizyczne wyrażone są za pomocą abstrakcyjnego formalizmu matematycznego, natomiast $-\mathrm{z}$ racji swojego przednaukowego charakteru - mechanika arystotelesowska w oryginalnym sformułowaniu opiera się na nieostrych pojęciach potocznych niemających charakteru operacyjnego i nienadających się do wykorzystania w prawach fizyki opartych na mierzalnych wielkościach. Trzeba też pamiętać, że w czasach Arystotelesa pod pojęciem mechaniki rozumiano coś zupełnie innego niż stanowiące część współczesnej fizyki teorie ruchu. Mechanika opisywała działanie takich układów fizycznych, jak np. dźwignie jedno- i dwustronne czy wielokrążki (Arystoteles 1978: 285-345). Nazywanie arystotelesowskiej teorii ruchu lokalnego, która nas tu interesuje, mechaniką wynika głównie z dość powszechnie przyjmowanego przez fizyków założenia o jej związkach z mechaniką newtonowską. Jak jednak podkreśla Heller, Arystoteles nie sformułował w ścisłym sensie teorii ruchu lokalnego, ponieważ jest to możliwe jedynie przy użyciu rachunku różniczkowego zakładającego ciągłość przestrzeni. Zdaniem Hellera Arystoteles mógł mieć jedynie pewne wstępne intuicje na ten temat, na wypracowanie precyzyjnego pojęcia ciągłości przestrzeni $\mathrm{w}$ sensie topologicznym potrzeba było jeszcze ponad dwóch tysięcy lat (Heller 1993: 13-15).

Największą trudność przy rekonstrukcji dynamiki Arystotelesa wydają się stwarzać pojęcia czynnika poruszanego, czyli ciała, oraz czynnika poruszającego. W prawach ilościowych znalazły zastosowanie będące ich odpowiednikami pojęcia masy i siły (por. Heller 1987: 152-163). Studia historyczne pokazują wyraźnie złożoność występujących między tymi grupami pojęć zależności oraz ich znaczną semantyczną rozbieżność (por. np. Jung-Palczewska 2002: 57-110). Ponadto w samym kontekście sformalizowanych teorii pojęcie masy zmieniło swoje znaczenie przy przejściu od mechaniki newtonowskiej do teorii względności. Zamierzone stylizacje obciążone są więc automatycznie konsekwencjami niewspółmierności teorii. Wskazuje to możliwą odmienność semantyki pojęć mechaniki arystotelesowskiej w stosunku do zmatematyzowanego formalizmu teorii późniejszych (por. np. Jodkowski 1984).

Przy rekonstrukcji mechaniki arystotelesowskiej, a także wszystkich chronologicznie następujących po niej czasoprzestrzennych teorii ruchu, przy użyciu pojęcia wiązek włóknistych wychodzi się od zdefiniowania implikowanej przez rozważaną teorię struktury czterowymiarowej czasoprzestrzeni, w której każ- 
demu jej punktowi (zdarzeniu) przypisuje się położenie określone przez jedną współrzędną czasową $t$ i trzy współrzędne przestrzenne $x, y$ i $z$. Nietrudno zauważyć, że takie rozumienie czasu i przestrzeni jest Arystotelesowi zdecydowanie obce, ponieważ wyobrażał sobie Wszechświat jako zamkniętą sferyczną przestrzeń, ograniczoną sferą gwiazd stałych i nieposiadającą rozciągłości we współczesnym rozumieniu. Podobnie rzecz miała się z czasem, ponieważ Arystoteles pojmował go czysto potocznie jako „miarę ruchu ze względu na przed i po" (Arystoteles 1990: 220a). Dokonywane stylizacje skutkują więc nie tylko istotnymi zmianami w znaczeniach odpowiednich pojęć, lecz także prowadzą do zdecydowanej przebudowy ontologii wynikającej z mechaniki arystotelesowskiej.

Jaki płynie więc pożytek z rekonstrukcji mechaniki arystotelesowskiej za pomocą wysoce abstrakcyjnych struktur matematycznych, takich jak wiązki włókniste? Będąc świadomym rysujących się trudności pojęciowych, w które rekonstrukcje te są uwikłane, Heller zwraca uwagę na korzyści poznawcze (por. np. 1993: 9-12, 35-36). Podkreśla, że wykorzystanie tego typu strategii pozwala ujrzeć tę mechanikę z perspektywy nowszych osiągnięć nauki wyposażonych w bardziej zaawansowane narzędzia badawcze, które odniosły sukces w opisie struktur czasoprzestrzeni, a właściwych dynamice Newtona i teorii względności Einsteina. Można bowiem w ten sposób lepiej wydobyć fizyczną treść omawianych teorii, zwłaszcza że „teorie fizyczne są mądrzejsze od ich twórców", czyli są treściowo bogatsze w stosunku do tego, co ich twórcy potrafili $\mathrm{w}$ ramach dostępnej im bazy pojęciowej wyartykułować. Potwierdza to zresztą przywoływany nie tylko przez Hellera (Heller 1993: 166-167), ale i Rogera Penrose'a (Penrose 2005: 388-390) fakt, że gdyby Galileusz i Newton znali teorię wiązek włóknistych, to niemal natychmiast zauważyliby możliwość uogólnień wypracowanych w wielkim trudzie przez Einsteina. Innymi słowy, w odpowiednio bogatej strukturze możliwości uogólnień jawią się jako oczywiste, a ich odkrycie nie wymaga długoletnich prac.

\section{WIĄZKI WŁÓKNISTE}

Wiązki włókniste są podstawowym teoretycznym narzędziem rekonstrukcji czasoprzestrzennych teorii ruchu pozwalającym na uchwycenie wewnętrznej logiki rozwoju fizyki. Stanowią wysoce abstrakcyjne matematyczne narzędzie umożliwiające budowanie iloczynów dwóch przestrzeni topologicznych i uogólnienie pojęcia iloczynu kartezjańskiego. Znajdują szerokie zastosowanie w geometrii różniczkowej, ponieważ warunkują bardziej naturalne definicje 
takich podstawowych struktur tej geometrii, jak wektory styczne, pola wektorowe, koneksje czy też krzywizny. Z punktu widzenia fizyki ważne jest, że wchodzące $\mathrm{w}$ skład wiązek przestrzenie można wyposażyć w różnorakie symetrie. Takie zresztą były między innymi motywy stojące za wprowadzeniem wiązek włóknistych do fizyki cząstek elementarnych, gdzie oddziaływania opisuje się za pomocą symetrii cechowania (por. Heller 1988: 53-55, Penrose 2005: 325-327).

Z racji matematycznego zaawansowania pojęcia wiązki włóknistej przedstawiona zostanie jedynie jej poglądowa definicja, która wystarcza na potrzeby analiz filozoficznych (por. Penrose 2005: 325-356, Heller 1988: 53-74; 2005: 52)1. Zgodnie z definicją przedstawioną przez Hellera jako wiązkę określa się trójkę ( $E, \pi, B)$, gdzie $E, B$ są przestrzeniami topologicznymi, a $\pi: E \rightarrow B$ to odwzorowanie ciągłe. Przestrzeń $E$ nosi miano przestrzeni totalnej, $B-$ przestrzeni bazowej, a $\pi$ odwzorowania rzutowego. Jeżeli weźmiemy dowolny punkt $x$ należący do przestrzeni bazowej $B$ i skonstruujemy przekształcenie $\pi^{-1}(\mathrm{x})$ będące przekształceniem odwrotnym do $\pi$, to wówczas $\pi^{-1}(\mathrm{x})$ nazywać się będzie „włóknem nad $x$ ”. Aby jednak wiązkę można było nazwać włóknistą, każde $\mathrm{z}$ włókien $\pi^{-1}(\mathrm{x})$ dla wszystkich $\mathrm{x} \in B$ musi być homeomorficzne z pewną przestrzenią topologiczną $F$, zwaną włóknem typowym. Jeżeli dodatkowo każde włókno ma strukturę grupy, to wiązkę taką określa się mianem głównej wiązki włóknistej, a odpowiednią grupę - grupą strukturalną wiązki. Mówiąc bardziej obrazowo, nad każdym punktem $x$,,stoi całkowita kopia $F$ " (Penrose 2005: 328) i żadne z kopii nie są z innymi ,,posklejane”. Najprostszym przykładem wiązki włóknistej jest iloczyn kartezjański $B \times F$.

Przechodząc do konkretnych fizycznych realizacji, warto sięgnąć do nieformalnej prezentacji pokazującej konstrukcję wiązki włóknistej nad czterowymiarową czasoprzestrzenią (Heller 2005: 53-54). Modelem takiej czasoprzestrzeni w fizyce jest rozmaitość różniczkowa $M$ wyposażona w dodatkową strukturę zależną od kodowanej za jej pomocą treści fizycznej. Mówiąc najkrócej, rozmaitość różniczkowa to przestrzeń, która jest lokalnie izomorficzna z przestrzenią euklidesową. W odróżnieniu od Hellera, który pokazuje tę konstrukcję dla przypadku szczególnej teorii względności, przedstawię ją w formie ogólniejszej pozwalającej na jej zastosowanie do każdej czasoprzestrzennej teorii ruchu. W każdej takiej teorii centralną rolę odgrywa wyróżniona klasa ruchów, które odbywają się bez działania siły, czyli ruchów inercjalnych. Dlatego odpowiednie równania dynamiki są niezmiennicze względem przekształceń między inercjalnymi układami odniesienia, czyli są względem tych

\footnotetext{
${ }^{1}$ Pełne formalne wprowadzenie do teorii wiązek znajduje się w fachowych podręcznikach (np. Sulanke, Wintgen 1977).
} 
przekształceń symetryczne. Równania te mają więc właściwe sobie grupy symetrii. W przypadku omawianej przez Hellera szczególnej teorii względności jest to grupa Lorentza, natomiast inne teorie ruchu charakteryzowane będą przez inne grupy.

Wiązka nad czasoprzestrzenią powstaje następująco: w pewnym dowolnym punkcie $x$ należącym do danej rozmaitości czasoprzestrzennej $M$ wybiera się dowolny inercjalny układ odniesienia $p_{x}$, który przekształca się zgodnie z właściwą danej teorii ruchu grupą symetrii, wskutek czego otrzymuje się wszystkie możliwe inercjalne układy odniesienia w tym punkcie. Jeżeli czasoprzestrzenną rozmaitość $M$ potraktuje się jako przestrzeń bazową wiązki, to zbiór wszystkich powiązanych relacją symetrii inercjalnych układów odniesienia tworzy włókno $F_{x}$ nad $x$. Nietrudno zauważyć, że liczba takich układów odniesienia powstałych po zastosowaniu operacji symetrii równa się liczbie tych operacji w danej grupie. Jak zauważa Heller, obydwa zbiory są homeomorficzne pod warunkiem zdefiniowania odpowiednich topologii. Gdy konstrukcję włókna powtórzy się nad każdym punktem rozmaitości $M$, otrzymuje się wiązkę włóknistą inercjalnych układów odniesienia dla danej teorii ruchu nad czasoprzestrzenną rozmaitością $M$. Przestrzeń totalna wiązki wyznaczona jest przez zbiór wszystkich inercjalnych układów odniesienia we wszystkich punktach tej rozmaitości. Grupa symetrii wiążących ze sobą wszystkie inercjalne układy odniesienia tworzy grupę strukturalną wiązki.

\section{ARYSTOTELES ,W WIAZZKACH”}

Jednym z głównych celów prowadzonych przez Hellera analiz rekonstrukcji czasoprzestrzennych teorii ruchu od Arystotelesa przez Einsteina do modeli kwantowania grawitacji jest ukazanie wewnętrznej logiki przejść międzyteoretycznych oraz skonstruowanie nieliniowego modelu rozwoju nauki (Heller 1984, 1988, 1993: 168-180; 2006b). Podstawową przesłanką istnienia wewnętrznej logiki rozwoju nauki jest niezmienniczość struktury iloczynu kartezjańskiego (zwanej dalej dla uproszczenia struktura iloczynowa) w wiązkowych reprezentacjach czasoprzestrzennych teorii ruchu od mechaniki Arystotelesa przez mechanikę Newtona do ogólnej teorii względności Einsteina ku przestrzeniom totalnym wiązek, będących coraz bardziej abstrakcyjnymi opisami czasoprzestrzeni (Heller 2006b). Ideę poszukiwania niezmienników, które pozwoliłyby pokazać racjonalność rozwoju nauki, wyraził już Henri Poincaré w polemice z Édouardem Le Roy. Poincaré doszukiwał się niezmienników powszechnych następujących po sobie teorii, warunkujących niezależność 
praw przyrody od konwencji pojęciowych (Poincaré 1908: 157). W ten sposób chciał dać uzasadnienie poznawczego, a nie jedynie pragmatycznego charakteru nauki. Głębokie związki między niezmienniczością a obiektywnością akcentował też Hermann Weyl (1952: 129-132, por. także Kosso 2003).

$\mathrm{W}$ analizach wiązkowych reprezentacji czasoprzestrzennych teorii ruchu oraz określanej na ich podstawie logiki przejść międzyteoretycznych Heller stroni od wniosków natury ontologicznej. Skoro jednak struktura iloczynowa $\mathrm{w}$ tych reprezentacjach stanowi niezmiennik przy przejściach do teorii o wyższym stopniu uogólnienia, to naturalne wydaje się pytanie o to, na ile struktura ta może odwzorowywać ontologię obiektywnej rzeczywistości fizycznej w sensie niezmienniczości i realności struktur zaproponowanym przez Johna Worralla (1989).

Ważnym matematycznym argumentem na rzecz tezy, że struktura iloczynowa w wiązkowej reprezentacji czasoprzestrzennych teorii ruchu może stanowić składnik fundamentalnej ontologii świata, jest rola, jaką iloczyn kartezjański odgrywa w teoriomnogościowym zdefiniowaniu pojęcia struktury (por. np. Bagaria 2016). Chodzi tu zwłaszcza o teoriomnogościową definicję par uporządkowanych, których iloczyn kartezjański jest zbiorem. Istotną ze względu na rozumienie pojęcia struktury relację określa się natomiast jako odpowiedni podzbiór iloczynu kartezjańskiego. Strukturę stanowi więc zbiór przedmiotów wraz z dołączonymi do niego relacjami będącymi odpowiednio zdefiniowanymi podzbiorami iloczynu kartezjańskiego (por. np. Heller 2006a). Ponieważ struktura iloczynowa warunkuje istnienie dowolnej relacji jako swojego podzbioru, to można ją uznać za bardziej fundamentalną od takich podstawowych struktur stosowanych w fizyce, jak funkcja, grupa, przestrzeń wektorowa czy algebra. Skoro oparta na aksjomatyce ZFC teoria mnogości uważana jest dzisiaj za fundament matematyki (por. np. Murawski 2001: 173-203), a iloczyn kartezjański bezpośrednio z jej aksjomatyki wynika, to można słusznie przypuszczać, iż obecność struktury iloczynu kartezjańskiego w wiązkowych reprezentacjach czasoprzestrzennych teorii ruchu świadczy o tym, że reprezentacje te mogą odwzorowywać istotny aspekt strukturalnej ontologii obiektywnej rzeczywistości fizycznej. Trzeba jednak pamiętać, że rozumienie struktury w sensie teoriomnogościowym jest dość prymitywne, ponieważ w teoriomnogościowym ufundowaniu matematyki ontycznie pierwotne są przedmioty. Aby lepiej zauważyć fundamentalny charakter struktury iloczynowej, można użyć wysoce abstrakcyjnej teorii kategorii, według której wiązkowe reprezentacje czasoprzestrzennych teorii ruchu zawierające tę strukturę charakteryzują się właściwą sobie naturalnością, wykazującą również głębokie związki z obiektywnością (por. np. Heller 1988: 148-164). Z uwagi na matematyczną złożoność tych pojęć, ich omówienie zdecydowanie wykracza poza ramy tego studium. 
W ramach każdej dynamicznej teorii ruchu formułuje się dwie zasady dynamiki. Pierwsza określa specyfikę ruchów bez działania siły, czyli ruchów inercjalnych. Druga natomiast podaje, jak zmieniają się parametry ruchu pod wpływem działania siły. Tak rzecz się ma w powszechnie znanej mechanice newtonowskiej, ale także i w mechanice arystotelesowskiej ${ }^{2}$. W mechanice arystotelesowskiej pierwsza zasada dynamiki głosi, że bez przyłożonej siły wszystkie ciała znajdują się w spoczynku. Wyróżniony jest więc absolutny spoczynek, wyznaczony przez przestrzeń absolutna, w rezultacie czego jako ruch inercjalny kwalifikuje się tylko ruch z zerową prędkością, czyli spoczynek. $\mathrm{W}$ takiej sytuacji zrozumiała staje się słynna arystotelesowska reguła, że ,,cokolwiek jest poruszane, poruszane jest przez coś innego" (Arystoteles 1990: 241b). Podobnie również rzecz ma się z czasem, który tak samo jak przestrzeń ma $\mathrm{w}$ tej mechanice charakter absolutny, przez co wszystkie zdarzenia są równoczesne dla wszystkich obserwatorów. Aby tę sytuację lepiej przybliżyć, Penrose posługuje się analogią ekranu kinowego, który przez bycie nieruchomym sprawia, że każdy punkt ekranu zachowuje swoje przestrzenne położenie w czasie niezależnie od tego, co jest na nim wyświetlane (Penrose 2005: 384). Choć Arystoteles nigdy nie podał ilościowego sformułowania drugiej zasady dynamiki, to jednak przedstawiona przez niego analiza ruchu (Arystoteles 1990: 250) pozwala na dokonanie stosownej rekonstrukcji (por. np. Heller 1993: 25-26). Zrekonstruowana za pomocą pojęć współczesnej fizyki druga zasada dynamiki w mechanice arystotelesowskiej przyjmuje postać $F=m v$. Ma ona swoje oczywiste uzasadnienie w zasadzie pierwszej, precyzującej dla dowolnej mechaniki warunki ruchu w momencie, kiedy nie działa siła.

Tak zrekonstruowaną mechanikę arystotelesowską można umieścić w abstrakcyjnym środowisku wiązek włóknistych (Heller 1988: 155-156, 2005: 80-82). Ujęcie w ścisłych kategoriach geometrycznych pokazuje, że zarówno czas, jak i przestrzenie chwilowe $\mathrm{w}$ mechanice arystotelesowskiej wyposażone są w strukturę metryczną Euklidesa. Jeżeli więc zbuduje się arystotelesowską czasoprzestrzeń jako iloczyn kartezjański współrzędnej czasowej oraz współrzędnej przestrzennej: $A=T \times S$, to rzut $\pi_{s}$ dowolnego punktu na kierunek przestrzenny wyznaczy przestrzeń absolutną, natomiast rzut $\pi_{t}$ na kierunek czasowy wyznaczy czas absolutny. Skoro więc przestrzeń $S$ i przestrzeń $T$ są przestrzeniami metrycznymi, to także czasoprzestrzeń $A$ musi być przestrzenią metryczną. Nietrudno jest więc zauważyć, że czasoprzestrzeń mechaniki arystotelesowskiej jest wiązką $\left(A, \pi_{s}, S\right)$, która ze względu na swoją bezpośrednią tożsamość z iloczynem kartezjańskim nosi miano wiązki trywialnej.

${ }^{2}$ Arystoteles przedstawił zarys dynamicznej teorii ruchu w siódmej księdze Fizyki. 
Aby precyzyjniej uchwycić ważne prawidłowości, warto przedstawić alternatywne spojrzenie na reprezentację czasoprzestrzeni mechaniki arystotelesowskiej $A$ jako wiązki trywialnej. W tym celu wykorzystuje się pokazaną wcześniej ogólną metodę tworzenia wiązki układów odniesienia nad czasoprzestrzenią. Ponieważ dla tej mechaniki istnieje dokładnie jeden inercjalny układ odniesienia związany z przestrzenią absolutną, to odpowiadająca takiej sytuacji grupa strukturalna to trywialna grupa jednoelementowa $E$ zawierająca operację identyczności. Nad każdym punktem czasoprzestrzeni stoi więc włókno złożone z jednego układu odniesienia, czyli przestrzeni absolutnej, $\mathrm{w}$ wyniku czego tak powstała przestrzeń totalna trywialnej wiązki, oznaczona jako $F(A)$, jest tożsama z czasoprzestrzenią mechaniki arystotelesowskiej. Przestrzeń ta ma strukturę iloczynową $T \times S$, którą można również zapisać jako $F(A)=A \times E$.

Czas teraz postawić pytanie o własności zmian w wiązkowej reprezentacji czasoprzestrzennych teorii ruchu przy przejściu od mechaniki arystotelesowskiej do mechaniki newtonowskiej i dalej do szczególnej i ogólnej teorii względności. Specyfikę tę ujmuje schemat zaproponowany przez Hellera (1988: 162). Jeśli chodzi o przesuwanie się struktury iloczynowej, to obserwowana tendencja jest dość jednoznaczna: przy przejściu od mechaniki arystotelesowskiej do mechaniki newtonowskiej bez grawitacji struktura ta przenosi się z czasoprzestrzeni $A$ jako wiązki trywialnej do przestrzeni totalnej $F(N)$ wiązki układów odniesienia nad czasoprzestrzenią $N$ właściwą tej mechanice, czyli czasoprzestrzenią afiniczną. Przestrzeń $F(N)$ przyjmuje wówczas postać $F(N)=N \times G$, gdzie $N$ oznacza zbiór punktów czasoprzestrzeni, a $G$ grupę Galileusza jako grupę strukturalną. Sytuacja praktycznie nie zmienia się przy przejściu do szczególnej teorii względności, gdzie struktura iloczynowa nadal znajduje się w przestrzeni totalnej $F(M)$ wiązki układów odniesienia nad czasoprzestrzenią Minkowskiego $M$. W podobny sposób $F(M)=$ $M \times L$, gdzie $M$ to zbiór punktów czasoprzestrzeni, natomiast $L$ to grupa strukturalna będąca grupą Lorentza. W przejściach tych ma miejsce również kilka pomniejszych modyfikacji struktury wiązkowej, które w obecnie prowadzonych analizach zostaną pominięte. Kolejne przekształcenie struktury iloczynowej następuje w ogólnej teorii względności, gdzie struktura ta wędruje, mówiąc kolokwialnie ,,jeszcze piętro wyżej”, to jest do wiązki układów odniesienia $F(F(M))$ nad wiązką układów odniesienia $F(M)$ nad czasoprzestrzenią $M$. Ponieważ nie sposób obecnie wchodzić w matematyczne zawiłości tego „piętra”, wystarczy jedynie zaznaczyć, że odnośna struktura iloczynowa uzyskuje swoją precyzyjną interpretację w środowisku geometrii nieprzemiennych jako grupoid $\Gamma=F(M) \times R$, gdzie $R$ to odpowiednia grupa strukturalna (por. np. Heller 2006b). 
Pierwszym oczywistym wnioskiem na temat własności opisywanych zmian jest to, że wraz z uogólnieniem teorii struktura iloczynowa przenosi się na poziom struktur o coraz wyższym stopniu abstrakcji. Wiąże się to niewątpliwie ze wzrostem złożoności sytuacji fizycznej przy każdym kolejnym kroku uogólnienia. W pierwszym $\mathrm{z}$ nich między mechaniką arystotelesowską a newtonowską bez grawitacji wzrost złożoności wynika z unifikacji spoczynku i ruchów jednostajnych prostoliniowych. W drugim natomiast - między szczególną a ogólną teorią grawitacji - wzrost podyktowany jest unifikacją grawitacji i bezwładności, co ujawnia się w matematycznie wyrafinowanej tensorowej strukturze równania pola grawitacyjnego. Wzrost abstrakcji opisu fizycznego wraz z uogólnieniem teorii komentował już zresztą Einstein, twierdząc, że w wyniku tego procesu powiązania między zjawiskami przesuwają się ku pojęciom i strukturom matematycznym coraz bardziej oddalającym się od sfery bezpośredniego doświadczenia (Einstein 2001: 16). Przekonanie Einsteina, że poznawczy dostęp do poziomów rzeczywistości poza obszarem bezpośredniej zmysłowej obserwacji umożliwia jedynie abstrakcyjny język matematyki, stanowi dziś powszechnie podzielany pogląd.

Po drugie, mając na względzie omówione argumenty za związkiem struktury iloczynowej z tworzywem fizycznego świata, można podejrzewać, że - z racji swojej najniższej pozycji ze względu na położenie tej struktury - mechanika arystotelesowska w niewielkim, lecz jednak niezerowym stopniu odsłania naturę obiektywnej rzeczywistości fizycznej. Już na tym etapie rozważań widać, że nie jest ona całkowicie fałszywa, ponieważ poprawnie identyfikuje dokładnie jeden przypadek ruchu ciał, gdy nie działa siła: ruch z zerową prędkością, czyli spoczynek. Problem ma jednak jeszcze bardziej złożoną naturę, która znajdzie niebawem szersze wyjaśnienie w modelu Rovellego.

Po trzecie, niewymieniony w sekwencji teorii, ale ciekawy przypadek stanowi mechanika newtonowska uwzględniająca oddziaływanie grawitacyjne. Reprezentacja wiązkowa tej teorii nie ma struktury iloczynowej w wiązce układów odniesienia nad właściwą jej czasoprzestrzenią. Struktura ta pojawia się dopiero w ogólnej teorii względności. Empiryczną adekwatność tej teorii dla słabej grawitacji i małych prędkości można jednak uzasadnić, wskazując, że o prawdziwości teorii łącznie decydują zgodność z doświadczeniem oraz kryteria wewnątrzteoretyczne. Doskonałą empiryczną adekwatność przejawia przecież pozostawiający wiele do życzenia pod względem wewnętrznej spójności standardowy model cząstek elementarnych. Istotę kryteriów wewnątrzteoretycznych akcentował szczególnie Einstein (2001: 155), dla którego ważnym wyznacznikiem poprawności teorii była jej logiczna prostota. Braku struktury iloczynowej w mechanice newtonowskiej z grawitacją można upatrywać w zbyt małym, używając terminologii Penrose’a, wyrafinowaniu 
matematycznej struktury tej mechaniki, niezdolnej do uchwycenia złożoności natury grawitacji.

Po czwarte, niezmiennicze przenoszenie się struktury iloczynowej w szeregu przebadanych wiązkowych reprezentacji czasoprzestrzennych teorii ruchu ku wyższym poziomom abstrakcji wzmacnia dodatkowo matematyczny argument na rzecz uznania tej struktury za składową ontologii świata. Niezmienniczości tej towarzyszy jednak istotna nieciągłość w zmianach innych elementów reprezentacji wiązkowej, takich jak własności czasoprzestrzeni jako przestrzeni bazowej wiązki czy też jej grupy strukturalnej. Przykładowo przy przejściu od mechaniki newtonowskiej bez grawitacji do szczególnej teorii względności czasoprzestrzeń afiniczna zmienia się $\mathrm{w}$ czasoprzestrzeń Minkowskiego, natomiast grupa strukturalna z grupy Galileusza w grupę Lorentza. Można też wskazać wiele innych nieciągłości, jak choćby sama zmienność poziomu ulokowania struktury iloczynowej. Widać więc, że schemat ten wspiera argument Worralla za realizmem strukturalnym, zachowującym to, co „najlepsze z dwóch światów”: istnieje niezmienniczy element strukturalny oraz nieciągłość $\mathrm{w}$ postulowanych przez daną teorię obiektach teoretycznych. Jeżeli więc wszystkie czasoprzestrzenne teorie ruchu, z mechaniką arystotelesowską włącznie, logicznie układają się w jeden ciąg poszerzającego się uogólnienia przy wspólnym strukturalnym niezmienniku, to efekt ten powinien manifestować się w ciągłości przejść teoretycznych. W tym celu należy przede wszystkim zbadać, jak w tych przejściach działa zasada korespondencji. Posłużymy się rekonstrukcją mechaniki arystotelesowskiej zaproponowaną przez włoskiego fizyka teoretyka Carla Rovellego³.

\section{NEWTONOWSKI MODEL ROVELLEGO}

Wyjątkowość rekonstrukcji Rovellego tkwi przede wszystkim w tym, że to, co powszechnie traktowane jest jako błąd Arystotelesa uniemożliwiający mu sformułowanie poprawnej dynamiki, Rovelli traktuje jako wartościowe źródło informacji. Tak motywuje swoją rekonstrukcję:

Po przetłumaczeniu na język współczesnej fizyki arystotelesowska fizyka ruchu może być postrzegana jako wysoce nietrywialne i empirycznie poprawne przybliżenie rzeczywistego zachowania ciał w ruchu ograniczonych do sfery ziemskiej, dla której ta teoria została stworzona (Rovelli 2015: 30).

3 Rovelli wniósł znaczący wkład do fizyki dzięki pracom nad teorią kwantowej grawitacji, w których rozwija podejście zwane pętlową kwantowa grawitacją (por. np. Rovelli 2004). 
Całokształt dociekań Rovellego koncentruje się na wskazaniu racji za powiązaniem mechaniki arystotelesowskiej z mechaniką newtonowską zasadq korespondencji, która charakteryzuje również dalsze przejście do teorii względności Einsteina i mechaniki kwantowej. Rovelli twierdzi, że w swoim obszarze adekwatności mechanika arystotelesowska poprawnie opisuje zjawiska fizyczne, tak jak mutatis mutandis poprawny opis gwarantuje mechanika newtonowska, jeżeli nie uwzględni się efektów relatywistycznych.

Przyjęta przez Rovellego strategia badawcza ma kilka ciekawych własności. Po pierwsze, Rovelli definiuje obszar empirycznej adekwatności mechaniki Arystotelesa, twierdząc, że jest to „obszar, w którym jako ludzie prowadzimy nasze działania" (2015: 30). Trudno chyba o bardziej rozmytą i nieprecyzyjną definicję. Można jednak słusznie podejrzewać, że ma tu na myśli ograniczone do sfery ziemskiej zdroworozsądkowe poznanie przednaukowe opierające się na biernej obserwacji i niekorzystające z eksperymentów. Po drugie, jako model dla formalnego ujęcia mechaniki Arystotelesa Rovelli obiera szczególny przypadek mechaniki newtonowskiej, którym jest ruch ciał w sferycznym polu grawitacyjnym w takich ośrodkach, jak powietrze czy woda oraz ruch ciał niebieskich widocznych z Ziemi. W swoich rozważaniach nie uwzględnia rekonstrukcyjnych prac Penrose'a, Trautmana oraz Hellera. Wprowadzając model ciał poruszających się w lepkich ośrodkach, przytacza jedynie prace Moniki Ugaglii $(2004,2013)$, nie powołując się chociażby na oparte na podobnych założeniach rekonstrukcje fizyki Arystotelesa zaproponowane przez Stephena Toulmina i June Goodfield (1961). Po trzecie, za empiryczną podstawę konstrukcji swojego modelu Rovelli bierze wiele obserwacji i klasyfikacji ruchu, które Arystoteles przedstawił głównie w trzech podstawowych dziełach na ten temat: Fizyce, O niebie oraz $O$ powstawianiu i ginięciu. Analizę dynamiki Arystotelesa Rovelli przeprowadza zgodnie z następującym podziałem: 1) ruchy ziemskie kolejno dla przypadków a) ruchów naturalnych i b) ruchów wymuszonych oraz osobno 2) ruchy sfer niebieskich.

W swoim newtonowskim modelu ciała zanurzonego w cieczy Rovelli rozważa działające na ciało w takim układzie siły, a mianowicie siłę grawitacji, siłę wyporu, opór ruchu w cieczy oraz pozostałe możliwe siły zewnętrzne

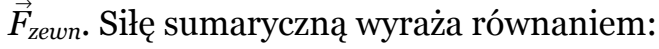

$$
\vec{F}=-G \frac{m M}{r^{2}} \vec{z}+V p \vec{z}-C p|v| \vec{v}+\vec{F}_{\text {zewn }},
$$

gdzie $\vec{z}$ oznacza jednostkowy wektor prostopadły do powierzchni Ziemi, $V$ i $\rho$ odpowiednio objętość badanego ciała i gęstość cieczy, w którym jest zanurzone, $\vec{v}$ prędkość ciała i $C$ współczynnik zależny od jego powierzchni i kształtu. Człon $-C p|v| \vec{v}$ wyraża wartość siły oporu aero- lub hydrodynamicznego typo- 
wego dla ruchu dużych obiektów z niezbyt małymi prędkościami, takich jak piłki, rowerzyści czy samochody. Model Toulmina i Goodfield zakłada natomiast małe prędkości i dlatego wykorzystuje prawo Stokesa, dające liniową zależność siły oporu od prędkości. Skoro więc człon oporu w równaniu (1) opisuje ruch typowych ciał $\mathrm{w}$ takim typowym dla ziemskiego obszaru obserwacji ośrodku, jaki stanowią powietrze lub ciecz, na potrzeby dalszych analiz mechaniki zaproponowanej przez Arystotelesa można założyć, że człon ten adekwatnie modeluje efekty tarcia.

Choć Rovelli nie określa tego jednoznacznie, to z metodologicznego punktu widzenia proponowany przez niego model opiera się na faktualizacji. Faktualizacja, zabieg przeciwny do idealizacji, oznacza uwzględnienie w równaniu dynamiki Newtona dodatkowych czynników pomijanych w wyidealizowanych modelach zjawisk (por. np. Grobler 2006: 168-175). W takiej sytuacji równanie (1) istotnie oddaje specyfikę metody Arystotelesa, zgodnie z którą zjawiska traktowane były w ,,całej swojej złożoności”. Bardziej precyzyjne znaczenie tego sformułowania stanie się jasne w dalszych analizach.

Aby jednak mieć pełną świadomość specyfiki i ograniczeń modelu Rovellego w perspektywie konkretnych zastosowań, warto przedstawić kilka uwag krytycznych. O ile Rovelli przekonuje, że jego model jest zgodny z empirycznymi obserwacjami Arystotelesa, takimi jak zależność szybkości spadania od ciężaru ciała, to jednak trudno w tych analizach dostrzec, jaki dokładnie charakter mają odpowiednie przejścia graniczne między mechaniką newtonowską i arystotelesowską. Nie jest więc jasne, jak precyzyjnie określić działanie zasady korespondencji. Jak już sygnalizowałem, model Rovellego jawi się bardziej jako szczególny przypadek mechaniki newtonowskiej dla ruchu ciała zanurzonego w cieczy, a nie osobna dynamika. Warto więc zastanowić się, czy odpowiada mu czasoprzestrzeń właściwa mechanice newtonowskiej bez absolutnych przestrzeni chwilowych, czy też mechanice arystotelesowskiej, gdzie czas i przestrzenie chwilowe mają charakter absolutny.

Model Rovellego pozwala rozwiać te wątpliwości, jeśli przyjrzymy się analizie ruchu uwzględniającej siłę oporu aerodynamicznego. Jeżeli w równaniu (1) modelu Rovellego pominie się siłę grawitacji oraz siłę wyporu i pozostawi jedynie siłę oporu, to otrzymamy:

$$
\vec{F}=-C p|v| \vec{v}+\vec{F}_{\text {zewn }} .
$$

Istotna z punktu widzenia prowadzonych analiz sytuacja pojawi się jednak wtedy, gdy siła zewnętrzna $\vec{F}_{\text {zewn }}$ przestanie działać i ciało poruszać się będzie jedynie dzięki swojej bezwładności. Stosowne równanie różniczkowe dla $\vec{F}_{\text {zewn }}=$ o przyjmuje postać: 
(3)

$$
m \frac{d v}{d t}=-C p v^{2},
$$

ponieważ kierunek działania siły oporu jest zawsze taki sam, jak kierunek prędkości. Podane przez Rovellego rozwiązanie tego równania przedstawia się następująco:

$$
v(t)=\frac{m}{C_{p}} t^{-1} .
$$

Czas wskazać kilka interesujących wniosków z równania (4). Po pierwsze, wraz z upływem czasu prędkość ciała zanika asymptotycznie do zera, a szybkość tego zaniku jest tym większa, im większa jest stała parametryzująca własności ciała $C$ (m.in. jego kształt), gęstość cieczy $\rho$ oraz im mniejsza jest masa bezwładna $m$. Po drugie, wysokie wartości tych stałych mogą powodować na tyle dużą szybkość zaniku prędkości $v$, że przy odpowiednio małej rozdzielczości czasowej pomiaru de facto potwierdzi się obserwacyjny postulat Arystotelesa, według którego jeżeli poruszyciel (siła) nie działa, to ruch natychmiast ustaje. Innymi słowy, gdy efekty oporu zdominują efekty bezwładności, łatwo można ulec złudzeniu, że warunkiem ruchu ciała jest działanie siły, co uzasadniałoby arystotelesowską regułę: omne quod movetur ab alio movetur (cokolwiek jest poruszane, poruszane jest przez coś innego). Ściśle rzecz biorąc, równanie (4) dopuszcza taką sytuację jako przypadek graniczny, gdy $C \rightarrow \infty$ lub $\rho \rightarrow \infty-$ co jest równoważne nieskończonemu oporowi - albo $m \rightarrow 0$. Z oczywistych względów przypadek $m=0$ nie ma sensu fizycznego, natomiast gdyby opór ruchu osiągał nieskończoność, to żaden ruch nie byłby możliwy. W bezpośredniej potocznej obserwacji bardzo łatwo jest też dostrzec kontrprzykłady dla reguły Arystotelesa, kiedy poruszające się ciała nadal się poruszają po utracie kontaktu z poruszycielem. Po trzecie, parametry $C, \rho$ oraz $m$ wchodzą do równania (4) jako iloraz $\frac{m}{c p}$, przez co równanie to umożliwia rozróżnienie między efektami oporu i efektami bezwładności, ponieważ efekt rosnących stałej $C$ i gęstości cieczy $\rho$ jest przeciwny do efektu rosnącej bezwładności $m$. Nie dysponując jednak metodą eksperymentalną ani definicjami operacyjnymi odpowiednich wielkości, Arystoteles nie potrafił dokonać stosownej dla mechaniki newtonowskiej idealizacji, ponieważ $\mathrm{w}$ warunkach biernej obserwacji efekty oporu mogą skutecznie maskować efekty bezwładności i w ten sposób uniemożliwiać ich wzajemne odseparowanie. Po czwarte, brak działania siły zewnętrznej $\vec{F}_{\text {zewn }}$ poruszającej ciało wcale nie oznacza, że na ciało nie działa żadna siła, ponieważ dopóki ciało jest w ruchu, dopóty podlega ono działaniu siły oporu. Można więc skonstatować, że realizuje się tu pierwsza zasada mechaniki arystotelesowskiej, zgodnie z którą jeśli na ciało nie działają żadne siły, to ciało spoczywa, a jego spoczynek ma charakter absolutny. Pamiętać jednak trzeba, że siła oporu nie jest siłą wywołującą ruch 
(przyczyną), lecz skutkiem ruchu, co prowadzi do słusznej wątpliwości, czy tak rozumiana zasada dynamiki na to miano w pełni zasługuje.

Przedstawione ustalenia dają tło pozwalające odpowiedzieć na pytanie o właściwą modelowi Rovellego strukturę czasoprzestrzeni. W tym celu trzeba zauważyć, że prędkość występująca w równaniu (4) jest zawsze prędkością mierzoną względem medium, w którym dane ciało się porusza. Oznacza to, że $\mathrm{w}$ tak zdefiniowanej sytuacji układ odniesienia na stałe związany jest $\mathrm{z}$ tym medium, przez co też wyraźnego sensu nabiera absolutny spoczynek, ponieważ w warunkach potocznej obserwacji rozmiary badanych przedmiotów są znikomo małe w stosunku do otaczających je ośrodków. Ośrodki te mogą wręcz odgrywać rolę absolutnej przestrzeni, co wskazywałoby na to, że model Rovellego zakłada strukturę czasoprzestrzeni właściwą mechanice arystotelesowskiej.

Adekwatność modelu Rovellego da się jeszcze dodatkowo uzasadnić dzięki analizie grup symetrii właściwych czasoprzestrzeniom mechaniki arystotelesowskiej i mechaniki newtonowskiej bez grawitacji. O grupach tych była już mowa jako o grupach strukturalnych $\mathrm{w}$ ich wiązkowych reprezentacjach: czasoprzestrzeni mechaniki arystotelesowskiej odpowiada kodująca własności metryczne grupa Euklidesa, natomiast czasoprzestrzeni mechaniki newtonowskiej grupa przekształceń określana mianem grupy Galileusza. Z uwagi na fakt, że po wprowadzeniu absolutnego spoczynku grupa Galileusza redukuje się do swojej podgrupy będącej grupą Euklidesa (por. np. Earman 1989: 33-35), czasoprzestrzeń mechaniki arystotelesowskiej można traktować jako szczególny przypadek czasoprzestrzeni mechaniki newtonowskiej. Ponieważ redukcja ta ewidentnie zachodzi, gdy w równaniu dynamiki uwzględni się siłę oporu jako szczególny przypadek mechaniki newtonowskiej, można uznać, że rekonstrukcja Rovellego poprawnie modeluje mechanikę arystotelesowską. Bardzo podobną dynamikę wyprowadzić można przy użyciu laminarnego modelu Toulmina i Goodfield.

Wyniki modelu Rovellego pozwalają na bardziej szczegółowe przedstawienie funkcjonowania zasady korespondencji między mechaniką arystotelesowską a mechaniką newtonowską. Nie ulega wątpliwości, że zasada ta jest powszechnie traktowana przez fizyków jako kryterium ciągłości przy analizie przejść międzyteoretycznych w procesie uogólniania teorii. Taką też zresztą miał motywację Rovelli, konstruując swój model. Choć za twórcę tej zasady uważa się Nielsa Bohra, to jednak najczęściej przytaczanym jej przykładem jest przejście między mechaniką newtonowską a szczególną teorią względności. W momencie bowiem, gdy w transformacji Lorentza przyjmie się nieskończoną prędkość rozchodzenia się sygnałów w przyrodzie, $c \rightarrow \infty$, co właściwe jest mechanice newtonowskiej, lub też rozważy się ruchy z prędkościami $v \rightarrow$ o, wów- 
czas transformacja Lorentza w granicy przechodzi w transformację Galileusza. Nietrudno zauważyć, że na granicy mechaniki arystotelesowskiej i newtonowskiej sytuacja kształtuje się nieco inaczej. Heller twierdzi nawet, że na granicy tych dwóch teorii zasada korespondencji załamuje się ze względu na zbyt mały poziom uteoretyzowania formalizmu mechaniki arystotelesowskiej i wynikającą z tego niezdolność do uchwycenia zależności międzyteoretycznych (Heller 1993: 178). Rodzi się więc pytanie, jak w takim razie zinterpretować obecność struktury iloczynowej w wiązkowej reprezentacji czasoprzestrzeni mechaniki arystotelesowskiej.

Przedstawione rozumienie zasady korespondencji w sensie przejść granicznych nie jest jedynym możliwym i zasadę tę można ujmować jako relację między dwoma teoriami, z których jedna jest szczególnym przypadkiem drugiej. Jest to dokładnie taka relacja, jaką zidentyfikowano w dotychczasowych analizach związków między mechaniką arystotelesowską i mechaniką newtonowską. Rozróżnienie między dwoma sensami zasady korespondencji omawiają Jan Such i Małgorzata Szcześniak (2002: 98-102), pierwszemu rozumieniu nadając miano eksplanacyjnego, a drugiemu implikacyjnego. Twierdzą także, że rozumienie implikacyjne jest słabsze i istnieją wątpliwości, czy w ogóle zasługuje na miano zasady korespondencji. W przejściu między mechaniką arystotelesowską a mechaniką newtonowską działa zasada korespondencji w sensie implikacyjnym, pierwsza teoria jest bowiem szczególnym przypadkiem drugiej. Ciągłość tego przejścia uzyskuje także swoje uzasadnienie w tym, że - identycznie jak w sensie eksplanacyjnym - towarzyszy mu niezmienniczość struktury iloczynowej mimo ewidentnej zmiany struktury czasoprzestrzeni wynikającej ze zmiany odpowiadającej jej grupy symetrii. Niezmienniczość ta przemawia również za traktowaniem implikacyjnie rozumianej zasady korespondencji jako adekwatnie ujmującej ciągłość przejść międzyteoretycznych.

\section{PODSUMOWANIE}

Przechodząc do podsumowania przeprowadzonych w tym studium analiz, należy wpierw zaznaczyć, że zestawienie ze sobą dwóch odmiennych metod rekonstrukcji mechaniki arystotelesowskiej w języku współczesnej fizyki pozwoliło dostrzec racje, dla których mechanikę tę można włączyć w ciąg rozwoju fizyki jako poprzedniczkę mechaniki newtonowskiej i teorii względności. Za takim wnioskiem przemawiają: 1) obecność struktury iloczynowej jako niezmienniczej składowej wiązkowych reprezentacji tych teorii niezależnie od 
stopnia uogólnienia oraz (2) obowiązywanie zasady korespondencji (choć w osłabionej wersji) przy przejściu między mechaniką arystotelesowską a mechaniką newtonowską. Związki struktury z fundamentalną ontologią świata znajdują natomiast swoje uzasadnienie w matematycznych własnościach iloczynu kartezjańskiego.

Na podstawie przedstawionych analiz uzasadnione wydaje się twierdzenie, że Arystoteles w ogóle nie skonstruował osobnej mechaniki, lecz de facto opisał szczególny jej przypadek - ruch w stawiającym opór ośrodku. Zaproponowane przez Hellera równanie mechaniki arystotelesowskiej $F=m v$ zasługuje na miano zasady dynamiki jedynie dla absolutnego spoczynku. Może to zabrzmieć paradoksalnie, ale jeśli rzeczywiście przyjmie się słuszność zasady dynamiki Arystotelesa jedynie dla spoczynku, to zasada korespondencji w sensie przejść granicznych pozwala powiązać wszystkie czasoprzestrzenne teorie ruchu, jeśli jako odpowiednią zmienną osiągającą wartości graniczne potraktuje się prędkość. I tak: teoria względności to teoria poprawna dla prędkości bliskich prędkości światła, mechanika newtonowska funkcjonuje poprawnie dla prędkości niezerowych, ale dużo mniejszych od prędkości światła, natomiast mechanika arystotelesowska jest adekwatna, gdy prędkość zdąża do zera, czyli gdy ustaje wszelki ruch. Pozostaje tylko pytanie, czy teoria, która poprawnie mówi jedynie o spoczynku, jest teorią ruchu.

Nie ulega wątpliwości, że nie dysponując metodą eksperymentalną, a jedynie biernie obserwując przyrodę, Arystoteles nie był w stanie wprowadzić stosownych idealizacji i odkryć poprawnego równania mechaniki newtonowskiej. Model Rovellego pokazał momenty, w których ze względu na słabość swojej metody badawczej Arystoteles mylnie zinterpretował obserwacje, w rezultacie czego niesłusznie podniósł do rangi zasady ruchu regułę omne quod movetur ab alio movetur. Trudno się więc dziwić, że jako anomalię traktował ruch ciał niebędących w fizycznym kontakcie z poruszycielem, co samo w sobie nie jest sprzeczne z przewidywaniami modelu Rovellego. Często spotykana opinia o fałszywości mechaniki arystotelesowskiej wynika najprawdopodobniej z utożsamiania jej z tą regułą, co łatwo prowadzi do konstatacji, że błędy w opisie ruchu w mechanice arystotelesowskiej są widoczne „,gołym okiem”. Rzecz ma się zupełnie inaczej w wypadku efektów relatywistycznych, obserwowalnych dopiero przy prędkościach równych $1 / 3 \mathrm{c}$. Ponieważ potoczna obserwacja nigdy tego typu zjawisk nie rejestruje, nieporównywalnie łatwiej jest przyznać absolutną prawdziwość mechanice newtonowskiej. W tym też można by chyba dopatrywać się wielkiej estymy, którą cieszyła się do czasów powstania teorii względności. Jak stwierdza Zygmunt Hajduk, powodem, dla którego stosuje się mechanikę newtonowską, jest zaniedbywalność generowanego przez nią błędu w stosunku do szczególnej teorii względności (Hajduk 
2002: 128). Ponieważ błąd generowany przez zasadę Arystotelesa ujawniał się niemal natychmiast, mechanika arystotelesowska z latwością zakwalifikowana została jako fałszywa.

Przynależność mechaniki arystotelesowskiej do ciągu współczesnych teorii fizycznych podporządkowanych wspólnej logice rozwoju naukowego zyskałaby swoje dalsze uzasadnienie, gdyby nadać jej jeszcze precyzyjniejszą ontologiczną interpretację struktury iloczynowej, a w szczególności precyzyjniej związać ją jako niezmiennik z jakimś elementem ontologii poziomu fundamentalnego. Warto bowiem zauważyć, że w kwantowo-grawitacyjnym modelu zaproponowanym przez Hellera i jego współpracowników struktura iloczynowa nie pojawia się w przestrzeni wiązki układów odniesienia, lecz w skonstruowanym nad nią grupoidzie (por. np. Heller, Odrzygóźdź, Pysiak, Sasin 2004, Heller, Pysiak, Sasin 2005). Oznacza to, że struktura ta nie angażuje bezpośrednio czasoprzestrzeni, ale określone na niej operacje symetrii. Innymi słowy, struktura iloczynowa jawi się nadal jako strukturalny niezmiennik teorii mimo wyeliminowania z niej jakichkolwiek odniesień czasoprzestrzennych. Oczywiście nie można wykluczyć, że dalsza unifikacja fizyki doprowadzi kiedyś do zakwestionowania także niezmienniczości struktury iloczynowej. Pewności w tej kwestii nie może dostarczyć nawet lansowana współcześnie jako wysoce adekwatna reprezentacja struktur rzeczywistości fizycznej teoria kategorii (Heller 2014) ani jakakolwiek inna teoria będąca jej hipotetycznym dalszym uogólnieniem.

\section{BIBLIOGRAFIA}

Arystoteles (1978), Mechanika [w:] Dzieła różne, tłum. L. Regner, Warszawa: Państwowe Wydawnictwo Naukowe, 285-345.

Arystoteles (1990), Fizyka [w:] Dzieła wszystkie, t. 2, tłum. K. Leśniak, Warszawa: Państwowe Wydawnictwo Naukowe.

Bagaria J. (2016), Set Theory [w:] The Stanford Encyclopedia of Philosophy (Winter 2016 Edition), E. N. Zalta (ed.), https://stanford.io/2We4R5x.

Earman J. (1989), World Enough and Space-Time: Absolute versus Relational Theories of Space and Time, Cambridge, Mass.-London: The MIT Press.

Einstein A. (2001), Bertrand Russell a myślenie filozoficzne [w:] Albert Einstein. Pisma filozoficzne, S. Butryn (red.), tłum. K. Napiórkowski, Warszawa: De Agostini-Altaya.

Grobler A. (2006), Metodologia nauk, Kraków: Aureus-Znak.

Hajduk Z. (2002), Metodologia nauk przyrodniczych, Lublin: Redakcja Wydawnictw KUL. Heller M. (1984), Nieliniowa ewolucja nauki, „Roczniki Filozoficzne” 22, 105-125.

Heller M. (1987), Ewolucja pojęcia masy [w:] Filozofować w kontekście nauki, M. Heller, A. Michalik, J. Życiński (red.), Kraków: Polskie Towarzystwo Teologiczne, 152-163. 
Heller M. (1988), Teoretyczne podstawy kosmologii, Warszawa: Państwowe Wydawnictwo Naukowe.

Heller M. (1993), Fizyka ruchu i czasoprzestrzeni, Warszawa: Wydawnictwo Naukowe PWN.

Heller M. (2005), Some Mathematical Physics for Philosophers, Vatican City-Rome: Pontifical Council For Culture, Pontifical Gregorian University.

Heller M. (2006a), Strukturalizm $w$ filozofii matematyki [w:] Filozofia i wszechświat, Kraków: Universitas, 197-214.

Heller M. (2006b), Evolution of the Space-Time Structures, „Concepts of Physics” 3, 117-131.

Heller M. (2014), The Field of Rationality and the Category Theory [w:] Mathematical Structures of the Universe, M. Eckstein, M. Heller, S. J. Szybka (eds.), Kraków: Copernicus Center Press, 441-457.

Heller M., Odrzygóźdź Z., Pysiak L., Sasin W. (2004), Noncommutative Unification of General Relativity and Quantum Mechanics: A Finite Model, „General Relativity and Gravitation” 36, 111-126. https://doi.org/10.1023/B:GERG.oooooo6697.80418.01

Heller M., Pysiak L., Sasin W. (2005), Noncommutative Unification of General Relativity and Quantum Mechanics, ,Journal of Mathematical Physics” 46, 122501-16. https:// doi.org/10.1063/1.2137720

Jodkowski K. (1984), Teza o niewspótmierności w ujęciu Thomasa S. Kuhna i Paula K. Feyerabenda [w:] Realizm. Racjonalność. Relatywizm, t. 1, K. Jodkowski, K. J. Brozi (red.), Lublin: Wydawnictwo UMCS.

Jung-Palczewska E. (2002), Między filozofia przyrody i nowożytnym przyrodoznawstwem. Ryszard Kilvington i fizyka matematyczna $w$ średniowieczu, Łódź: Wydawnictwo Uniwersytetu Łódzkiego.

Kosso P. (2003), Symmetry, Objectivity, and Design [w:] Symmetries in Physics: Philosophical Reflections, K. Brading, E. Castellani (eds.), Cambridge: Cambridge University Press, 413-424. https://doi.org/10.1017/CBO9780511535369.026

Murawski R. (2001), Filozofia matematyki. Zarys dziejów, Warszawa: Wydawnictwo Naukowe PWN.

Pedersen O. (2007), The Two Books: Historical Notes on Some Interactions between Natural Science and Theology, Vatican: Vatican Observatory Foundation.

Penrose R. (1968), The Structure of Space-Time [w:] Battelle Recontres, C. M. DeWitt, J. A. Wheeler (eds.), New York: Benjamin, 121-235.

Penrose R. (2005), The Road to Reality. A Complete Guide to the Laws of the Universe, New York: Alfred A. Knopf.

Poincaré H. (1908), Wartość nauki, Warszawa: G. Centnerszwer i Ska, Drukarnia Narodowa w Krakowie.

Raine D. J., Heller M. (1981), The Science of Space-Time, Tucson: Pachart.

Rovelli C. (2004), Quantum Gravity, Cambridge: Cambridge University Press. https:// doi.org/10.1017/CBO9780511755804

Rovelli C. (2015), Aristotle's Physics: A Physicist's Look, ,,Journal of the American Philosophical Association" 1, 23-40, arXiv:1312.4057v2 [physics.hist-ph]. https://doi.org/ 10.1017/apa.2014.11

Russell B. (2011), Badania dotyczące znaczenia i prawdy, tłum. J. Wawrzyniak, Kraków: Wydawnictwo WAM.

Such J., Szcześniak M. (2002), Filozofia nauki, Poznań: Wydawnictwo Naukowe UAM.

Sulanke R., Wintgen P. (1977), Geometria różniczkowa i teoria wiązek, tłum. P. Kucharczyk, Warszawa: Państwowe Wydawnictwo Naukowe. 
Toulmin S., Goodfied J. (1961), The Fabric of Heavens, London-New York: Harper \& Row. Trautman A. (1970), Fibre Bundles Associated with Spacetime, ,Reports on Mathematical Physics" 1, 29-62. https://doi.org/10.1016/0034-4877(70)90003-0

Trautman A. (1973), Theory of Gravitation [w:] The Physicist's Conception of Nature, J. Mehra (ed.), Dordrecht-Boston: Reidel, 79-198. https://doi.org/10.1007/978-94010-2602-4_8

Ugaglia M. (2004), Modelli idrostatici del moto da Aristotele a Galileo, Rome: Lateran University Press.

Ugaglia M. (2013), Peso e peso specifico in Aristotele [w:] Science and Representations, P. Napolitani, R. Nanni (red.), Firenze: Olschki, 15-48.

Weyl H. (1952), Symmetry, Princeton: Princeton University Press.

Worrall J. (1989), Structural Realism: The Best of Two Worlds?, „Dialectica” 43, 99-124. https://doi.org/10.1111/j.1746-8361.1989.tboo933.x

Wróblewski A. K. (2007), Historia fizyki, Warszawa: Wydawnictwo Naukowe PWN. 